\title{
THE RELATIONSHIPS BETWEEN SELECTED ANTHROPOMETRIC AND SOCIO-ECONOMIC DATA IN SCHOOLCHILDREN FROM DIFFERENT SOCIAL STRATA IN RIO DE JANEIRO, BRAZIL*
}

\author{
Rainer Gross** \\ Fernão Dias de Lima*** \\ Cristina Jesus de Freitas**** \\ Ursula Gross**
}

\begin{abstract}
GROSS, R. et al. The relationships between selected anthropometric and socio-economic data in schoolchildren from different social strata in Rio de Janeiro, Brazil. Rev. Saúde públ., S Paulo, 24: 11-9, 1990.

ABSTRACT: The nutritional status according to anthropometric data was assessed in 756 schoolchildren from 5 low-income state schools and in one private school in the same part of Rio de Janeiro, Brazil. The prevalence of stunting and wasting (cut-off point: $<90 \% \mathrm{ht} / \mathrm{age}$ and $<80 \% \mathrm{wt} / \mathrm{ht}$ ) ranged in the public schools from 6.2 to $15.2 \%$ and 3.3 to $24.0 \%$, respectively, whereas the figures for the private school were 2.3 and $3.5 \%$, respectively. Much more obesity was found in the private school (18.0\%) than in the state schools $(0.8-6.2 \%)$. Nutritional problems seem to develop more severely in accordance with the increasing age of the children. Therefore it appears advisable to assess schoolchildren within the context of a nutritional surveillance system.
\end{abstract}

KEYWORDS: Nutritional status. Anthropometry. Socioeconomic factors.

\section{INTRODUCTION}

Since the recommendation to use anthropometric data as an indicator for the nutritional status of children, a fair amount of data has been collected on the anthropometric characteristics of preschool children in different parts of Brazil. In contrast to the rural areas and the northeastern and northern parts of the country, wasting and stunting of children aged up to six years is far less widespread in the southern and southeastern regions and in the urban areas $4,7,9,11,12,13,14,16$.

However, little information is available on the nutritional status of schoolchildren in Brazil ${ }^{2}$, 5,10 . The present study has the following objectives:

1. The assessment of the nutritional status of schoolchildren for the identification of possible interventions.

2. The identification of possible statistical relationships between anthropometric and socioeconomic data as nutritional indicators.

3. To determine whether measurement of the an- thropometric characteristics of schoolchildren should be used for nutritional surveillance in Brazil.

\section{METHODS}

\section{Population Studied}

In order to limit as much as possible ecological and sociogeographical conditions, pupils of six schools in the geographically isolated city quarters "Ilha do Governador" and "Ilha do Fundão" of Rio de Janeiro, Brazil, were studied. "Ilha do Governador" and "Ilha do Fundão" are islands in the bay of Guanabara (Figure 1). "Ilha do Governador" is the biggest island $\left(32 \mathrm{~km}^{2}\right)$ in the bay. Both islands are well connected by two bridges which lead to the center of the city, for "Ilha do Governador" is the site of the International Airport of Rio de Janeiro and "Ilha do Fundão" has the biggest university in the city (Universidade Federal do Rio de Janeiro). The state schools $\left(\mathrm{n}^{2} 1\right.$ - 5) are attended by 2,127 children from lowincome groups and were surveyed in 1985 (Table 1). The private school $\left(n^{2} 6\right)$ is attended by 1,254 children from middle-income families and was studied in 1986 (Table 1). In all schools pupils

\footnotetext{
* Supported by the Deutsche Gesellschaft für Technische Zusammenarbeit (GTZ) GmbH

* Deutsche Gesellschaft für Technische Zusammenarbeit (GTZ) GmbH, FB 412, P.O. Box 5180, D-6236 Eschborn, Federal Republic of Germany.

** Departamento de Epidemiologia da Faculdade de Saúde Pública da Universidade de São Paulo - Av. Dr. Arnaldo, 715 - 01255 - São Paulo, SP - Brasil.

* * * Instituto de Nutrição do Centro de Ciências da Saúde da Universidade Federal do Rio de Janeiro - Bloco J - $2^{2}$ andar - Cidade Universitária - Ilha do Fundão - 21941 - Rio de Janciro, RJ - Brasil.
} 




Fig. 1. Geographical location of the six surveyed schools in Rio de Janeiro.

from the 2 nd, 3 rd and 4 th years were assessed. Classes were randomly selected.

\section{Anthropometric Characteristics}

All anthropometric data were taken in accordance with the WHO recommendation ${ }^{20}$. Children were weighed on an electronic personal scale (SECA 770) graded in divisions of $100 \mathrm{~g}$. Children were weighed lightly clothed and without shoes. The height of the children was recorded using a metal tape measure fixed on an aluminum bar, on which a square can be moved up and down the bar to the top of the child's head.

\section{Questionnaire}

All questions on demographic, socio-economic and environmental characteristics were put by the same nutritionists to reduce interobserver bias. The answers were given by the mothers of the children.

\section{Data Processing}

All data were processed using the SPSS package on a Burroughs Large Systems Computer, Version $\mathrm{H}$, at the University of São Paulo. The anthropometric data were calculated using the Anthropometric Software Package ${ }^{8}$, which is based on the reference standard of the United States Center of Health Statistics (NCHS) in accordance with the recommendation of the WHO Working Group ${ }^{21}$. In case that the Anthropometric
Software Package could not be used for calculation due to increased age of schoolchildren all calculation of anthropometric indicators were made by hand according to NCHS reference population. The data were converted into height-for-age (ht/ age) and weight-for-height (wt/ht) indices (\% of NCHS standard) to discriminate between stunting and wasting ${ }^{19}$ and obesity.

Tests of specific derived subhypotheses were carried out using a series of variance analyses with unequal sample size (one-factor ANOVA). These tests avoid the exaggerated overestimation of smaller-sized sample groups which might occur in field studies. Furthermore, it allows the statistical differentiation not only of continuous variables, such as age groups, but also of discontinuous variables, such as the origin of parents.

\section{RESULTS}

\section{Population studied}

According to Table 1 the surveyed schoolchildren of low income groups are in average more than one year older than their counterparts of middle income households. Further the age distribution is more heterogenic in the public schools than in the private school. Sex distribution does not differ between both school types.

\section{Socio-economic and Socio-cultural Data}

Table 2 describes the socio-economic and socio- 
cultural data of the families of the schoolchildren. There are considerable differences between the observed socio-economic indicators of the middle-income households of school 6 and the low income households of schools 1 to 5 . Significantly fewer persons (4.6) live in the middle-income households and fewer of them (0.8 per household) work than in the low-income households $(p<0.01)$. All data confirm that the housing conditions (such as number of bedrooms, running water, flush toilet and electricity) of the middle-income families surveyed are better than the average of the households of the five low-income schools. Many more families of school 6 children own their houses $81 \%$ than do families of children from the other five schools $(10-57 \%)$. The dwelling area of the middle-income households of children from school 6 is equipped with a complete network of street lighting whereas lighting is incomplete in the living areas of the households with children from the other five schools (48-88\%).

School education of the parents, which is shown in Table 3, is another indicator for the socio-economic situation of the families. The parents of the children from school 6 had a significantly longer school education than those of children from schools $1-5.51 \%$ of the fathers of children from school 6 had more than 12 years formal education, whereas, with the exception of school 5, most fathers of children from the other schools had only 5 years school education. Regardless of socio-economic background (with the exception of school 2), in all other groups mothers had on average less school education than fathers.

The distribution of the origin of the parents may provide an indicator for the socio-cultural background of the communities attending the schools observed (Table 4). There are considerable differences as regards the origin of the parents within the communities. In contrast to the communities of all other schools, which are dominated by parents originating from the federal state of Rio de Janeiro, parents of school 3 children come mainly from the Northeast. Within the community of school 5, the percentage of parents originating from outside Rio de Janeiro is only of minor significance. In school 4, about one fourth of parents come from São Paulo. In school 1, around the same proportion of parents originate from the Northeast.

\section{Anthropometric Data}

In a comparison of weight and height of the younger children of school 6 and the rest of the surveyed children, the anthropometric data show that the children from the middle-income community are biologically normally developed, whereas the children from the low-income communities have lower weight and height (Figure $2 \mathrm{a}$ and $\mathrm{b}$ ).
This difference can be observed in both boys and girls. As regards the criterion of sex, boys are slightly taller $(138.3 \mathrm{~cm}$ and $137.4 \mathrm{~cm}$, respectively) and weigh less (32.2 kg and $32.5 \mathrm{~kg})$ than girls. However, these differences are not significant.

The retarded growth in the low-income group results in stunting which varied in schools $1-5$ between 6.2 and $15.2 \%$ (Table 5). A much higher variation is observed within the 5 schools with regard to wasting. The percentage of wasting is lowest in the children from school 5, with $3.3 \%$ within the range of a normal distribution of the NCHS reference population, whereas in school 1 it is dramatically high (24.0\%).

In the middle-income group from school 6, the proportion of stunted and wasted children lies within the normal distribution range (2.3 and $3.5 \%$, respectively). But there is a high proportion of obese children (18.0\%) which is not found in the five low-income group schools $(0.8-6.2)$.

Table 6 shows some statistical relationships between socio-economic and demographic data and selected anthropometric data within the group of schoolchildren of, low income communities. Sex does not significantly influence anthropometric characteristics. Age, however, bears a significant negative relationship to $\mathrm{ht} /$ age in the schoolchildren from low-income communities $(F=7.34 ; p<0.001)$. The difference between the expected and the observed ht/age increases with growing age of the children. The household size of the low-income communities bears a significant negative relationship to $\mathrm{ht} / \mathrm{age}$ and $\mathrm{wt} / \mathrm{ht}$ $(F=2.49 ; p=0.031)$. In households with more than 5 persons, wt/ht in the surveyed children decreases notably, whereas ht/age drops in households with more than 6 persons. School education and origin of the parents does not show any significant statistical relationship with anthropometric data. Children from low-income communities without flush toilets have a significant lower ht/ age $(\mathrm{F}=5.62 ; \mathrm{p}=0.021)$.

More statistical relationships between anthropometric and socio-economic data are found when schoolchildren from low and middle income communities are observed together. Age and size of family bear a marked relationship with anthropometric characteristics. A statistical relationship exists between school education of the parents and anthropometric characteristics of the pupils. Furthermore, some data of living conditions bear a relationship to the observed anthropometric data. Schoolchildren living in dwelling areas with street lighting have significantly higher wt/ht $(F=6.66 ; p=0.01)$ than those living in areas without lighting. Children whose parents are house owners and children whose houses have a large number of bedrooms have a significantly higher wt $/ \mathrm{ht}(\mathrm{F}=6.65 ; \mathrm{p}=0.010$ and $\mathrm{F}=3.23$; 
TABLE 1

Distribution of age and sex of schoolchildren according to the observed schools (number and \% of total surveyed low income and

middle income school children)

\begin{tabular}{|c|c|c|c|c|c|c|c|c|c|}
\hline \multirow{2}{*}{$\begin{array}{l}\text { Children } \\
\text { Characteristics }\end{array}$} & \multicolumn{7}{|c|}{$\begin{array}{c}\text { Schools } \\
\text { Low income group }\end{array}$} & \multicolumn{2}{|c|}{$\begin{array}{l}\text { Middle } \\
\text { income }\end{array}$} \\
\hline & $\begin{array}{l}1 \\
(n)\end{array}$ & $\stackrel{2}{(n)}$ & $\begin{array}{l}3 \\
(n)\end{array}$ & $\begin{array}{c}4 \\
(n)\end{array}$ & $\begin{array}{l}5 \\
\text { (n) }\end{array}$ & (n) & al $(\%)$ & (n) & (\%) \\
\hline Total children & 805 & 390 & 548 & 310 & 353 & 2,127 & & 1,254 & \\
\hline $\begin{array}{l}\text { Total surveyed } \\
\text { children }\end{array}$ & 102 & 105 & 116 & 68 & 93 & 484 & 100.0 & 272 & 100.0 \\
\hline $\begin{array}{c}\text { Age (years) } \\
7 \\
8 \\
9 \\
10 \\
11 \\
12 \\
13 \\
14 \\
15 \\
16 \\
17\end{array}$ & $\begin{array}{r}5 \\
7 \\
15 \\
17 \\
16 \\
20 \\
9 \\
15 \\
2 \\
1 \\
-\end{array}$ & $\begin{array}{r} \\
4 \\
21 \\
13 \\
19 \\
23 \\
11 \\
9 \\
4 \\
1\end{array}$ & $\begin{array}{r}3 \\
22 \\
41 \\
21 \\
12 \\
1 \\
11 \\
3 \\
1 \\
- \\
1\end{array}$ & $\begin{array}{r}- \\
- \\
4 \\
14 \\
18 \\
16 \\
6 \\
6 \\
3 \\
1 \\
-\end{array}$ & $\begin{array}{r}7 \\
7 \\
10 \\
26 \\
10 \\
15 \\
10 \\
12 \\
2 \\
1 \\
-\end{array}$ & $\begin{array}{r}3 \\
40 \\
91 \\
91 \\
75 \\
75 \\
47 \\
44 \\
12 \\
4 \\
1\end{array}$ & \begin{tabular}{r|}
0.6 \\
8.3 \\
18.8 \\
18.8 \\
15.5 \\
15.5 \\
9.6 \\
9.3 \\
2.5 \\
0.8 \\
0.3
\end{tabular} & $\begin{array}{r}30 \\
76 \\
81 \\
58 \\
27 \\
: \\
1 \\
\\
- \\
-\end{array}$ & $\begin{array}{r}11.0 \\
27.9 \\
29.5 \\
21.3 \\
9.9 \\
0.4 \\
. \\
.\end{array}$ \\
\hline Age (years)* & 11.9 & 10.4 & 11.0 & 10.5 & 10.1 & & & 7.8 & \\
\hline Sex (\% male) & 49.5 & 47.6 & 52.7 & 44.9 & 53.8 & & & 50.3 & \\
\hline
\end{tabular}

* statistical mean

TABLE 2

Selected characteristics of socio-economic, housing and basic infrastructure conditions of the families of the surveyed pupils of six schools in Ilha do Governador, Rio de Janciro $(1985 / 86)$.

\begin{tabular}{|c|c|c|c|c|c|c|}
\hline \multirow{2}{*}{$\begin{array}{l}\text { Family } \\
\text { characteristics }\end{array}$} & \multicolumn{5}{|c|}{$\begin{array}{c}\text { Schools } \\
\text { Low income group }\end{array}$} & \multirow{2}{*}{$\begin{array}{c}\begin{array}{r}\text { Middle } \\
\text { income }\end{array} \\
6\end{array}$} \\
\hline & 1 & 2 & 3 & 4 & 5 & \\
\hline $\begin{array}{l}\text { Household members: } \\
\text { Total } \\
\text { Working }\end{array}$ & $\begin{array}{l}5.6 \\
1.5\end{array}$ & $\begin{array}{l}6.3 \\
1.3\end{array}$ & $\begin{array}{l}6.4 \\
1.7\end{array}$ & $\begin{array}{l}6.7 \\
1.6\end{array}$ & $\begin{array}{l}6.1 \\
1.3\end{array}$ & $\begin{array}{l}4.6 \\
0.8\end{array}$ \\
\hline $\begin{array}{l}\text { Time of residence } \\
\text { (years) } \\
\text { Street lightning (\%) } \\
\text { House ownership (\%) }\end{array}$ & $\begin{array}{l}8.6 \\
81 \\
52\end{array}$ & $\begin{array}{r}7.5 \\
59 \\
35\end{array}$ & $\begin{array}{l}7.7 \\
88 \\
57\end{array}$ & $\begin{array}{l}7.2 \\
62 \\
10\end{array}$ & $\begin{array}{l}8.4 \\
48 \\
35\end{array}$ & $\begin{array}{l}6.5 \\
99 \\
81\end{array}$ \\
\hline $\begin{array}{l}\text { Housing conditons: } \\
\text { No of bedrooms } \\
\text { Running water (\%) } \\
\text { Flush toilet (\%) } \\
\text { Electricity (\%) }\end{array}$ & $\begin{array}{l}5.6 \\
96 \\
65 \\
98\end{array}$ & $\begin{array}{l}5.6 \\
89 \\
40 \\
90\end{array}$ & $\begin{array}{l}5.8 \\
95 \\
49 \\
99\end{array}$ & $\begin{array}{l}5.7 \\
88 \\
54 \\
96\end{array}$ & $\begin{array}{r}5.7 \\
97 \\
8 \\
100\end{array}$ & $\begin{array}{r}7.4 \\
100 \\
86 \\
100\end{array}$ \\
\hline
\end{tabular}

*tatistical mean 
TABLE 3

Distribution of illiteracy and formal school education of parents (\% of total surveyed fathers and mothers)

\begin{tabular}{|c|c|c|c|c|c|c|}
\hline \multirow{2}{*}{$\begin{array}{l}\text { Education } \\
\text { of } \\
\text { parents }\end{array}$} & \multicolumn{5}{|c|}{$\begin{array}{c}\text { Schools } \\
\text { Low income group }\end{array}$} & \multirow{2}{*}{$\begin{array}{r}\begin{array}{r}\text { Middle } \\
\text { income }\end{array} \\
6\end{array}$} \\
\hline & 1 & 2 & 3 & 4 & 5 & \\
\hline \multicolumn{7}{|l|}{ Fathers: } \\
\hline Illiterate & 0 & 2 & 5 & 3 & 4 & 0 \\
\hline 3-5 years & 39 & 52 & 41 & 47 & 40 & 4 \\
\hline $6-9$ years & 31 & 26 & 38 & 39 & 52 & 12 \\
\hline 10-12 years & 27 & 17 & 14 & 11 & 2 & 33 \\
\hline$>12$ years & 3 & 3 & 2 & 0 & 2 & 51 \\
\hline Total & 100 & 100 & 100 & 100 & 100 & 100 \\
\hline \multicolumn{7}{|l|}{ Mothers: } \\
\hline Illiterate & 1 & 0 & 8 & 5 & 11 & 0 \\
\hline $3-5$ years & 51 & 44 & 50 & 43 & 50 & 4 \\
\hline $6-9$ years & 38 & 50 & 28 & 47 & 34 & 20 \\
\hline $10-12$ years & 9 & 6 & 13 & 5 & 5 & 49 \\
\hline$>12$ years & 1 & 0 & 1 & 0 & 0 & 27 \\
\hline Total & 100 & 100 & 100 & 100 & 100 & 100 \\
\hline
\end{tabular}

TABLE 4

Distribution of origin of parents

(\% of total surveyed fathers and mothers)

\begin{tabular}{|c|c|c|c|c|c|c|}
\hline \multirow{2}{*}{$\begin{array}{l}\text { Origin } \\
\text { Families }\end{array}$} & \multicolumn{5}{|c|}{$\begin{array}{c}\text { Schools } \\
\text { Low income group }\end{array}$} & \multirow{2}{*}{$\begin{array}{r}\begin{array}{l}\text { Middle } \\
\text { income }\end{array} \\
6\end{array}$} \\
\hline & 1 & 2 & 3 & 4 & 5 & \\
\hline $\begin{array}{l}\text { Fathers: } \\
\text { Rio de Janeiro } \\
\text { São Paulo } \\
\text { Northeast } \\
\text { Other regions }\end{array}$ & $\begin{array}{r}56 \\
11 \\
25 \\
8\end{array}$ & $\begin{array}{r}69 \\
12 \\
19 \\
0\end{array}$ & $\begin{array}{r}38 \\
9 \\
48 \\
3\end{array}$ & $\begin{array}{r}66 \\
20 \\
9 \\
5\end{array}$ & $\begin{array}{r}87 \\
4 \\
7 \\
2\end{array}$ & $\begin{array}{r}55 \\
9 \\
17 \\
19\end{array}$ \\
\hline Total & 100 & 100 & 100 & 100 & 100 & 100 \\
\hline $\begin{array}{l}\text { Mothers: } \\
\text { Rio de Janeiro } \\
\text { São Paulo } \\
\text { Northeast } \\
\text { Other regions }\end{array}$ & $\begin{array}{r}60 \\
13 \\
24 \\
3\end{array}$ & $\begin{array}{r}56 \\
24 \\
18 \\
2\end{array}$ & $\begin{array}{r}47 \\
10 \\
41 \\
2\end{array}$ & $\begin{array}{r}56 \\
26 \\
18 \\
0\end{array}$ & $\begin{array}{r}80 \\
11 \\
9 \\
0\end{array}$ & $\begin{array}{l}54 \\
15 \\
13 \\
18\end{array}$ \\
\hline Total & 100 & 100 & 100 & 100 & 100 & 100 \\
\hline
\end{tabular}


TABLE 5

Age, weight, height and point prevalence of malnourished children of the six schools expressed by Waterlow classification (ht/age deficiency: stunting; cut-off point: $<90 \%$ - wt $/$ ht deficiency: wasting; cut-off point: $<80 \%$ ) and by obesity (wt/ht excess; cut-off point:>120\%).

\begin{tabular}{|c|c|c|c|c|c|c|}
\hline \multirow{2}{*}{$\begin{array}{l}\text { Children } \\
\text { characteristics }\end{array}$} & \multicolumn{5}{|c|}{$\begin{array}{l}\text { Schools } \\
\text { Low income group }\end{array}$} & \multirow{2}{*}{$\begin{array}{c}\begin{array}{c}\text { Middle } \\
\text { income }\end{array} \\
6 \\
\end{array}$} \\
\hline & 1 & 2 & 3 & 4 & 5 & \\
\hline $\begin{array}{l}\text { Age (years) } \\
\text { Weight (Kg) } \\
\text { Height (cm) }\end{array}$ & $\begin{array}{r}11.9 \\
36.9 \\
147\end{array}$ & $\begin{array}{r}10.4 \\
30.9 \\
137\end{array}$ & $\begin{array}{r}11.0 \\
34.8 \\
141\end{array}$ & $\begin{array}{r}10.5 \\
33.8 \\
142\end{array}$ & $\begin{array}{r}10.1 \\
28.9 \\
134\end{array}$ & $\begin{array}{r}7.8 \\
31.0 \\
134\end{array}$ \\
\hline $\begin{array}{l}\text { Stunted (\%) } \\
\text { Wasted (\%) }\end{array}$ & $\begin{array}{l}10.7 \\
24.0\end{array}$ & $\begin{array}{l}8.7 \\
7.5\end{array}$ & $\begin{array}{l}9.7 \\
7.9\end{array}$ & $\begin{array}{r}6.2 \\
21.9\end{array}$ & $\begin{array}{r}15.2 \\
3.3\end{array}$ & $\begin{array}{l}2.3 \\
3.5\end{array}$ \\
\hline $\begin{array}{l}\text { Stunted } \\
\text { and wasted }(\%)\end{array}$ & 0.8 & 0 & 0.9 & 0 & 0 & 0.6 \\
\hline Obese (\%) & 0.8 & 1.2 & 3.5 & 6.2 & 3.2 & 18.0 \\
\hline $\begin{array}{l}\text { Total malnourished } \\
\text { children (\%) }\end{array}$ & 35.5 & 17.4 & 21.2 & 34.3 & 21.7 & 23.8 \\
\hline $\begin{array}{l}\text { Total number of } \\
\text { surveyed children }\end{array}$ & 121 & 80 & 113 & 64 & 92 & 172 \\
\hline
\end{tabular}

TABLE 6

Statistical significance of socio-economic, demographic and experimental effects upon selected experimental effects (one-factor ANOVA; F-values and level of significance).

\begin{tabular}{|c|c|c|c|c|c|c|}
\hline \multirow[t]{2}{*}{$\begin{array}{l}\text { Family } \\
\text { Characteristics }\end{array}$} & \multicolumn{2}{|c|}{$\begin{array}{l}\text { Low income } \\
\text { schools }\end{array}$} & \multicolumn{2}{|c|}{$\begin{array}{l}\text { Middle income } \\
\text { school }\end{array}$} & \multicolumn{2}{|c|}{$\begin{array}{c}\text { All } \\
\text { schools }\end{array}$} \\
\hline & ht/age & $w t / h t$ & ht/age & wt/ht & ht/age & wt $/ \mathrm{ht}$ \\
\hline $\begin{array}{l}\text { Individual data: } \\
\text { Sex } \\
\text { Age } \\
\text { School performance }\end{array}$ & $\begin{array}{l}0.55 \\
1.16 \\
0.93\end{array}$ & $\begin{array}{l}<0.01 \\
7.34^{* * *} \\
1.40\end{array}$ & $\begin{array}{l}1.71 \\
1.07 \\
1.74\end{array}$ & $\begin{array}{l}0.07 \\
2.23 \\
1.98\end{array}$ & $\begin{array}{l}0.05 \\
5.04^{* * 4} \\
0.45\end{array}$ & $\begin{array}{c}<0.01 \\
15.8^{* * 4 *} \\
0.84\end{array}$ \\
\hline $\begin{array}{l}\text { Household members: } \\
\text { Total } \\
\text { Working }\end{array}$ & $\begin{array}{l}2.26^{*} \\
0.55\end{array}$ & $\begin{array}{l}0.37 \\
0.09\end{array}$ & $\begin{array}{l}0.71 \\
0.31\end{array}$ & $\begin{array}{l}1.73 \\
1.13\end{array}$ & $\begin{array}{l}2.49^{*} \\
1.97\end{array}$ & $\begin{array}{l}3.60^{* *} \\
1.05\end{array}$ \\
\hline $\begin{array}{l}\text { School education: } \\
\text { Father } \\
\text { Mother }\end{array}$ & $\begin{array}{l}0.81 \\
2.07\end{array}$ & $\begin{array}{l}1.21 \\
0.56\end{array}$ & $\begin{array}{l}1.13 \\
0.06\end{array}$ & $\begin{array}{l}0.28 \\
0.58\end{array}$ & $\begin{array}{l}3.19^{* *} \\
5.15^{* * *}\end{array}$ & $\begin{array}{l}9.46^{* * *} \\
8.61^{* * *}\end{array}$ \\
\hline $\begin{array}{l}\text { Origin: } \\
\text { Father } \\
\text { Mother }\end{array}$ & $\begin{array}{l}0.35 \\
0.92\end{array}$ & $\begin{array}{l}0.96 \\
0.84\end{array}$ & $\begin{array}{l}0.61 \\
0.93\end{array}$ & $\begin{array}{l}0.44 \\
0.80\end{array}$ & $\begin{array}{l}1.06 \\
0.89\end{array}$ & $\begin{array}{l}1.68 \\
1.97\end{array}$ \\
\hline $\begin{array}{l}\text { Time of residence } \\
\text { Street lighting }\end{array}$ & $\begin{array}{l}1.63 \\
0.52\end{array}$ & $\begin{array}{l}1.02 \\
0.02\end{array}$ & $\begin{array}{l}0.91 \\
0.12\end{array}$ & $\begin{array}{l}0.57 \\
0.29\end{array}$ & $\begin{array}{l}3.49^{* *} \\
1.08\end{array}$ & $\begin{array}{l}4.52^{* *} \\
6.66^{*}\end{array}$ \\
\hline $\begin{array}{l}\text { Housing conditions: } \\
\text { House ownership } \\
\text { No of bedrooms } \\
\text { Running water } \\
\text { Flush toilet } \\
\text { Electricity }\end{array}$ & $\begin{array}{l}0.61 \\
0.59 \\
5.62^{\star} \\
1.53 \\
1.02\end{array}$ & $\begin{array}{l}1.61 \\
1.01 \\
0.07 \\
1.37 \\
0.47\end{array}$ & $\begin{array}{l}0.02 \\
1.26 \\
1.20\end{array}$ & $\begin{array}{l}0.58 \\
0.89 \\
0.01 \\
:\end{array}$ & $\begin{array}{l}1.40 \\
1.43 \\
3.01 \\
6.80^{\star n} \\
0.38\end{array}$ & $\begin{array}{l}6.65^{*} \\
3.23^{* *} \\
2.04 \\
3.00 \\
<0.01\end{array}$ \\
\hline
\end{tabular}

' Variance analyses were not realized due to lack of variability

Significance level:

* $\mathrm{p}<0.05$

* $\mathrm{p}<0.01$

*** $\mathrm{p}<0.001$ 
$p=0.007$, respectively). Children living in houses without flush toilets are shorter for their age $(F=6.80 ; p=0.001)$.

\section{DISCUSSION}

The comparison of children in primary schools is dominated by the fact that the children from the middle-income community in the same school year are younger than those from the low-income group. This is due to the lower age of school entry and the lower rate of school year repetition among the middle-income children. Although the age of the middle-income children is much lower, the biological development expressed in terms of anthropometric data is more or less the same as that of the low-income group. These data indicate that the middle-income children have several advantages over the low-income children. From an economic point of view, the children from the poorer communities need more time and therefore more money to compete with middle-income group children. This fact has been confirmed in other Latin American countries such as Colombia ${ }^{1}$ and Costa Rica ${ }^{17}$.

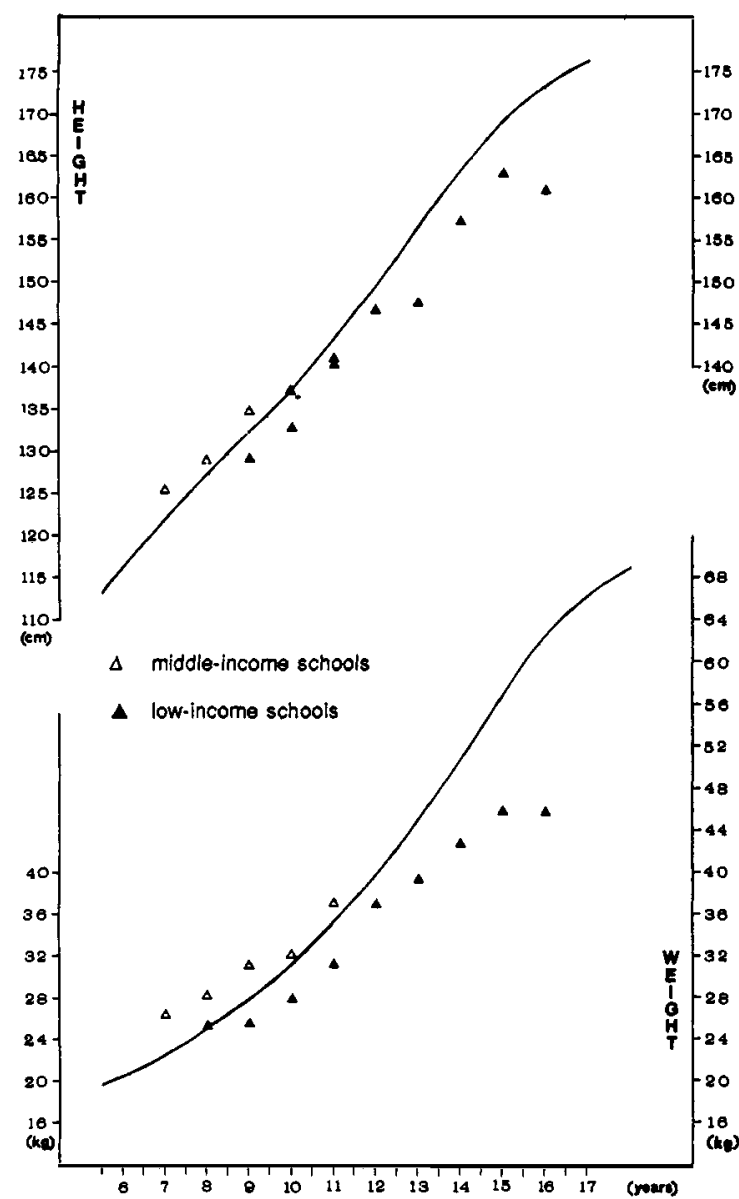

Fig. 2a. Height $(\mathrm{cm})$ and weight $(\mathrm{Kg})$ of different age groups ot school boys ot low income and middle income groups:
As shown in Table 5, from the point of view of anthropometric data it can be stated that the magnitude of the problem of malnutrition in the children from the middle-income community in the observed metropolitan area is no lower(23.8\%) than in the children from the low-income group communities (17.4 - 35.5\%). However, the type of problem differs in the two groups. The food energy supply of the low-income group is often too low to meet biological requirements, whereas in the case of middle-income group calory intake seems to be too high. This differentiation was also found in other schoolchildren in the State of São Paulo and Recife ${ }^{10}$ and pupils in Colombia ${ }^{1}$.

As has already been mentioned, there are many statistically significant relationships between the observed socio-economic variables and the anthropometric data of the children when all children are grouped together. This is due mainly to the different socio-economic conditions in the communities of children from schools 1.5 and children from school 6 . If the children are observed separately within their income group, many of the statistical relationships are no longer significant.

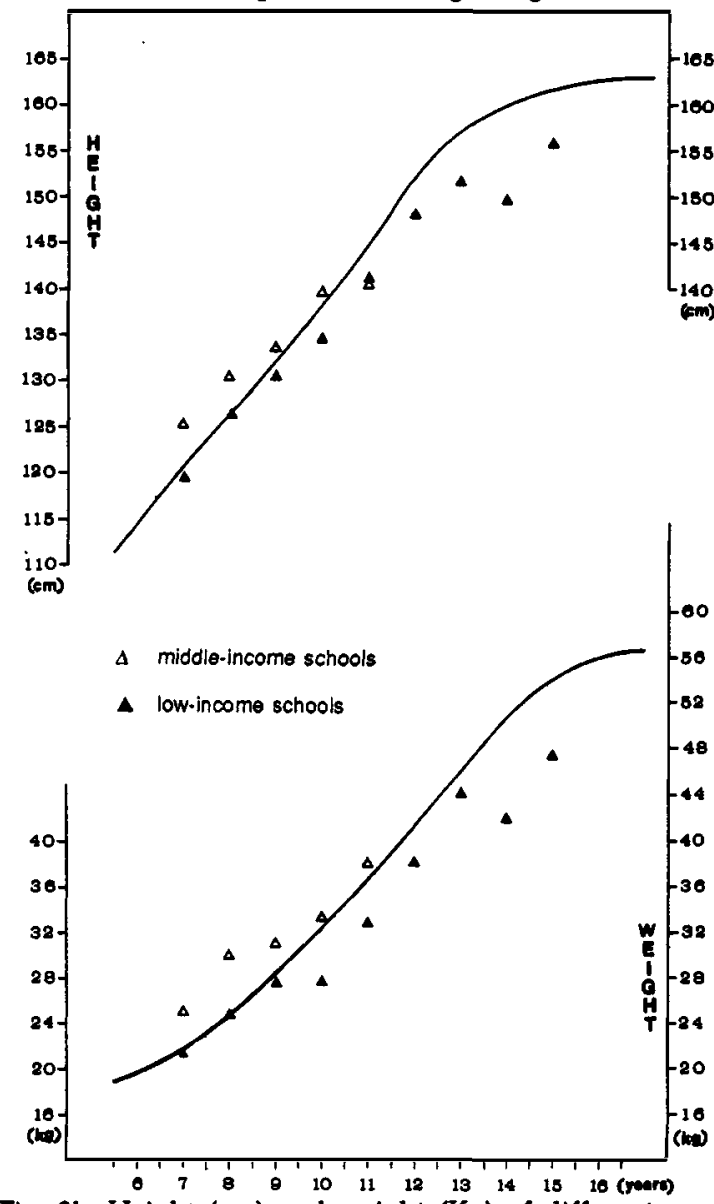

Fig. 2b. Height $(\mathrm{cm})$ and weight $(\mathrm{Kg})$ of different age groups of school girls of low income and middle income groups. 
There is a tremendous variation of prevalence of wasting between the schools of low income communities (3.3 -524.0\%). This may be due to the different age distribution within the schools. School 1 with the highest prevalence of wasting is attended from the oldest schoolchildren. However, it is unclear whether the high prevalence can be explained by the high age or both factors due to the same socio-economic factor(s).

With increasing age the difference between the average weight of a standard population of children and the observed weight of the lowincome communities increases. This fact has also been demonstrated in Brazilian pre-school children by other surveys 5,9 . This might be due to reduced care as regards food distribution within the family. Perhaps mothers think that the older children who go to school are already privileged enough by their participation in the school feeding program. Another reason could be the earlier onset of puberty in the middle-income children from school 6 , since it is known that children from economically better-off families and societies reach puberty earlier than those from poor communities 3,10 .

Moreover, low-income families face the potential problem that with the increase in the size of the family children are smaller for their age. It seems that the economic constraints increase with the number of children and limit the biological development of the children. Victora et al. ${ }^{16}$ found that the prevalence of stunting and low weight increases with the number of siblings already in pre-school aged children.

The source of water was the only variable which is responsible for the retarded growth development of the children in the low-income communities. Several studies have shown that repeated infections due to an inadequate water supply may lead to stunting in children $6,15,16$. However, it is equally possible that the general socio-economic and socio-cultural conditions of the families without adequate water supply lead to stunting and not the polluted water itself. The fact that the form of refuse disposal facilities does not influence the anthropometric data of children in a statistically significant way demon- strates that this factor is not of health relevance for this age group under the conditions observed.

Although there is an obvious variation as regards school education of the parents and family wage (indirectly measured by house ownership) within the low-income group, there is no significant relationship between these two factors and the anthropometric characteristics of the children. It is known from other studies that within the population of urban communities there is not necessarily a direct casual link between family wage and nutritional status ${ }^{11,18}$.

Finally it has to stress, that within the geographically very limited observed metropolitan area two completely different nutritional problems occur: undernutrition and obesity. The later problem was described in Brazil already in an earlier study by Artega et al. ${ }^{2}$. However, this problem which can be found in middle income communities seems to be still neglected in many developing countries.

\section{CONCLUSION}

It can be stated that in, low-income, urban communities of Brazil there may be a higher risk of wasting with increasing age of the children. This fact is reinforced by studies of different urban, low-income populations in Brazil, where it has been demonstrated that wasting in pre-schoolaged children is not a problem ${ }^{3,8,12}$. However, more studies on the magnitude and cause of wasting in schoolchildren are necessary.

Furthermore, it is important to realize that within the same city nutritional problem may vary substantially, as there may be cases of both undernutrition and overnutrition. This fact has to be taken into consideration in the field of public health nutrition, where diagnosis and interventions are often confined solely to undernutrition.

Finally, the question as to whether nutritional surveillance in urban areas should be extended to schoolchildren must be taken into consideration, since with increasing age the anthropometric indicators point to increasing nutritional probloms. 
GROSS, R. et al. Relaç̋̃es entre dados antropométricos e sócio-econômicos em escolares de diversas classes sociais, Rio de Janeiro, Brasil. Rev. Saúde públ., S. Paulo, 24: 11-9,1990.

RESUMO: O estado nutricional, de acordo com os dados antropométricos, foi avaliado em 756 escolares de cinco escolas estaduais de baixa renda e uma escola particular, na mesma área geográfica do Rio de Janeiro, Brasil. A prevalência de déficit de estatura/idade e de peso/altura (pontos de corte: $90 \%$ estatura/idade e $80 \%$ peso/estatura) encontrada nas escolas estaduais foi de 6,2 a $15,2 \%$ e 3,3 a $24,0 \%$, respectivamente, enquanto que na escola particular foi de 2,3 a 3,5\%, respectivamente. Maior número de obesos fol encontrado na escola particular (18\%). Os problemas nutricionais parecem ocorrer mais assiduamente com o aumento da idade das crianças. Recomenda-se avaliar os escolares dentro do contexto de um sistema de vigilância nutricional.

DESCRITORES: Estado Nutricional. Antropometria. Fatores sócio-econômicos.

\section{REFERENCES}

1. ALVAREZ, M. C. et al. Evaluación del estado nutricional de los escolares en Medellin (1982-1983). Medellin, Comite Central de Investigación, 1984.

2. ARTEGA; $H$. et al. Obesity among schoolchildren of different socioeconomic levels in a developing country. Int. J. Obse., 6: 291-7, 1982.

3. BARNES, V. H. Physical growth and development during puberty. Med. clin. N. Amer., 59: 1305-18, 1975.

4. BATISTA FILHO, M. \& BARBOSA, N. de P. Alimentação e nutrição no Brasil 1974-1984. Brasilia, Instituto Nacional de Alimentação e Nutrição, 1987.

5. DESAI, J. D. et al. Anthropometric and cycloergonometric assessment of the nutritional status of the children of agricultural migrant workers in Southern Brazil. Amer. J. clin. Nutr., 34: 1925-34, 1981.

6. ESREY, S. A. et al. Options for the control of diarrhoeal diseases among young children: improving water supplies and excreta disposal facilities. Bull. Wld Hlth Org., 63: 757-72, 1985.

7. GROSS, R. et al. The influence of economic deterioration in Brazil on the nutritional status of children in Rio de Janeiro, Brazil. Ecol. Food Nutr., 19: 265-79, 1987.

8. JORDAN, M. D. Anthropometric software package. Atlanta, Ga., U.S. Department of Health and Human Services/Public Health Service/Centers of Disease Control, 1986.

9. KNIGHT, P. \& MORAN, R. Brasil: poverty and basic need series. Washington, D.C., World Bank, 1981.

10. LINHARES, E. D. R. et al. Growth, bone maturation and biochemical changes in Brazilian children from two different socioeconomic groups. Amer.J. clin. Nutr., 44: $552-8,1986$.

11. MOLINA, C. M. B. et al. Nutritional status of children of urban low-income communities, Brazil (1986). Rev.
Saúde públ., S. Paulo, 23: 89-97, 1989.

12. MONTEIRO, C. A. et al. Estudo das condiçóes de saúde das crianças do Município de São Paulo, SP (Brasil), 19841985. II - Antropometria nutricional. Rev. Saúde públ., S. Paulo, 20: 446-53, 1986.

13. OLIVEIRA ASSIS, A.M. et al. Expropriaçāo e fome. Salvador, Escola de Nutrição UFBa, 1987.

14. REES, D. G. et al. Measures of nutritional status survey of young children in Northeast Brazil. Lancet, 1: 87-9, 1987.

15. TROWBRIDGE, F. L. Wasting and stunting as risk factors for morbidity and mortality. In: Intemational Congress of Nutrition, 13th, Brighton, 1985. Proceedings. London, John Libbey, 1986. p. 93-6.

16. VICTORA, C. G. et al. Risk factors for malnutrition in Brazilian children: the role of social environmental varisbles. Bull. Wld Hlth Org., 64: 299-309, 1986.

17. VILLAREJOS, V. et al. Height and weight of children in urban and rural Costa Rica. J. trop. Pediatr. 17: 32-43, 1981.

18. WALTER, J. P. Two poverties equal one hunger. J. Nutr. Educ., 5: 129-33, 1973.

19. WATERLOW, J.C. Classification and definition of protein calorie malnutrition. Brit. med. J., 3: 566-9, 1972.

20. WORLD HEALTH ORGANIZATTON. Measuring change in nutritional status. Geneva, 1983.

21. WORLD HEALTH ORGANIZATION GROUP. Use and interpretation of anthropometric indicators of nutritional status. Bull. Wld Hlth Org, 64: 929-41, 1986. 